\title{
SAR SI VON?** \\ A HAZAI CIGÁNY ÉRTELMISÉG HELYZETE EGY NEM REPREZENTATÍV KUTATÁS TÜKRÉBEN
}

\begin{abstract}
A hazai cigányság az elmúlt évtizedekben egyre öntudatosabbá vált, a rendszerváltás óta mind több cigány származású fiatal és kevésbé fiatal tanul felsóoktatási intézményeinkben. A többségi társadalom tagjaival ellentétben azonban az ó útjuk a diploma megszerzéséig jóval göröngyösebb, s lényegesen hosszabb. Kutatásomban arra kerestem a választ, hogy társadalmunk e stigmatizált, kisebbségi sorsban élő népének milyen lehetôsége van az értelmiségi létbe való felemelkedésre, s mekkora „árat” kell ezért fizetnie. Vizsgáltam, hogy válaszadóimat kik motiválták a tanulásra, cigány, illetve nem cigány környezetük miképp fogadta kiemelkedésüket, változott-e velük szemben a többségi társadalom magatartása, elszakadtak-e, s milyen mértékben gyökereiktől, s múködik-e még a hagyományos, megtartó rokoni kapcsolati rendszer. Helyzetüket és mentális állapotukat zárt és nyitott kérdéseket tartalmazó, általam készített kérdőívvel, valamint hazai és nemzetközi felmérésekben egyaránt használatos mentális állapotméró skálákkal, tesztekkel mértem.
\end{abstract}

Kulcsszavak: cigány kisebbség, többségi társadalom, értelmiség, mentális állapot

\section{A CIGÁNY ÉRTELMISÉG}

A cigány értelmiség kutatásának során ugyanabba a falba ütközik a kutató, mint amibe a cigányság történelmét feltárni, tanulmányozni kívánó szakember. A vizsgálódást ugyanis két tényezó is nehezíti: egyrészt a cigányság sajátos életmódja miatt nem alakult ki saját írásbeliségük, s nem jegyezték fel történelmüket, másrészt a hegeli történetfilozófia hatására a cigányság történelmét - mint nem államalapító nép történetét - a történészek nem is tartották méltónak arra, hogy lejegyezzék. Csupán a 20. században indultak szerteágazó kutatások az etnográfia, zenetudomány, kulturális antropológia, szociológia területén. Ennek következtében a cigány értelmiség kialakulásáról, szervezôdéséról is keveset tudtunk.

\footnotetext{
* Sz. Kármán Judit

Xport Mentálhigiénés és Kommunikációs Bt.

1141 Budapest, Negyed u. 24.

E-mail: szabo@ahbrt.hu

** Ôk hogy vannak? (lovári nyelven)
} 
Az bizonyos, hogy a 18. században már egyre több, külföldön tanult, magasan képzett zenész képviselte a cigány értelmiséget (Sárosi 1971). A 19. században feljegyzések készültek cigány származású írókról, költốkról, de munkáik nem maradtak ránk (Kemény 2000).

Az 1893-as országos cigányösszeírásban az alábbi megállapítás található: „Mindenekelőtt feltúnó az értelmiség csekély száma, amely semmi arányban sem áll azzal az értelmességgel, mellyel a cigányok jó része bír" (Hermann 1895).

A cigány értelmiség szerveződésének kezdete az 1970-es évek elejére tehető, s Lakatos Menyhért, Choli Daróczi József, Péli Tamás, Daróczi Ágnes és Kovács József nevéhez köthetô. Munkásszállásokon népmúvelóként, klubvezetóként vállaltak állást, együtteseket hoztak létre a cigány hagyományok, értékek ápolására. Kiállításokat szerveztek, egyre több cigány szerzố verseskötete, regénye jelent meg, s kiadták az elsó cigány újságokat. A nyolcvanas, kilencvenes években mind több szervezetet, alapítványt alapítottak a cigány értékek megmentésére, a cigányság jogainak képviseletére, a tehetséges, tanulni vágyó cigány fiatalok támogatására.

\section{A cigány értelmiség képzése}

A rendszerváltás óta eltelt idôszakban egyre több cigány fiatal tanul felsőoktatási intézményekben, s szerez gyakran nem egy, hanem több diplomát is.

Míg 1971-ben az ország cigány lakosságának 87\%-a nem rendelkezett általános iskolai végzettséggel, 1993-ra már 46\%-uk elvégezte a nyolc általánost. Az 1996/1997-es tanévben a felsóoktatásban tanuló cigány hallgatók száma mindössze 0,22 ezrelék volt. 2003-as felmérések szerint a 200 ezer fônyi nappali tagozatos diák 1,2\%-a, az esti és levelezố tagozatosok 2,5\%-a vallotta magát cigánynak, s ez több mint kétszerese az eddig ismert számadatoknak (Zsuppán 2003). A kedvezố tendenciát az is mutatja, hogy a cigány diákok között nyolcszor több az elsôs, mint az ötödéves.

A végzett diplomások egy jelentôs része hajlik az asszimilációra, a teljes beolvadásra, etnikai identitásuk feladására. Egy másik, polgárosodó rétegük azonban az integráció útját választja, nem adja fel identitását, cigányságában értéket lát. Ôk azok, akik részt vesznek a civil önszervezôdésben is, múvészi, irodalmi munkájuk, oktatói, jogi, közgazdászi, orvosi, kutatói tevékenységük mellett közéleti szerepet is vállalnak. 


\section{A KUTATÁS CÉLJAI, MÓDSZERTANA}

\section{Kutatásom célja, hipotéziseim}

Kutatásomban arra kerestem a választ, hogy a cigányságnak, társadalmunk e stigmatizált, kisebbségi sorsban élố népének milyen lehetôsége van az értelmiségi létbe való felemelkedésre, s mekkora "árat” kell ezért fizetnie. Vizsgáltam, hogy válaszadóimat kik motiválták a tanulásra, cigány, illetve nem cigány környezetük miképp fogadta kiemelkedésüket, változott-e velük szemben a többségi társadalom magatartása, s múködik-e még a hagyományos, megtartó rokoni kapcsolati rendszer.

Feltételeztem

- az értelmiségivé válás útján egy külsó segítô szerepét;

- az értelmiségivé válásért - erósen elóítéletes társadalmunkban - a cigányságnak súlyos árat kell fizetni, és az így kialakuló mentális állapotváltozások mérhetók lesznek;

- a diploma megszerzése után az érvényesülés, munkalehetôség miatt a fiatalok messzire költöznek szüleiktól, ezért a hagyományos közösség nyújtotta védôháló hiányzik az értelmiségivé vált cigány emberek életéból;

- a társas támogatottság hiánya kedvezótlenebb mentális állapotot eredményez;

- az alapítványi, egyesületi munka énvédóként múködhet az értelmiségi cigány emberek életében, ezért azt vártam, hogy a különféle szervezetekben tevékenykedô válaszadók mentális értékei jobbak lesznek;

- élve a nyitott kérdések adta lehetóségekkel, a válaszadók kifejtik gondolataikat, érzéseiket (pl. az óket ért diszkriminációval, munkahelyi nehézségekkel, elvárt segítségekkel stb. kapcsolatban).

\section{Kutatási minta, kutatási módszerem}

A hazai cigányság száma 500-600 ezer, ezen belül azonban az értelmiség körébe tartozók számáról még becslésekkel sem rendelkezünk. Ily módon reprezentatív mintáról e kutatás esetében szó sem lehetett.

Értelmiségi meghatározásomban a Kardos-féle értelmezést használom, e szerint értelmiségi az iskolázott (felsőfokú végzettséggel rendelkezó) ember (Kardos 1992). 
A „ki a cigány?”, illetve „ki a cigány értelmiségi?”, azaz kikre irányul a kutatás, válasza egyértelmú: az kerülhetett be a mintába, aki magát cigánynak vallja, s felsőfokú végzettséggel rendelkezik.

Ennek megfelelóen ún. „hólabda-módszerrel” jutottam el a válaszadókhoz. 2004 februárjában és márciusában 60 kérdóívet osztottam szét, s 51 értékelhetôt kaptam vissza. Az elsô kérdőív-kitöltók a Pécsi Tudományegyetem Bölcsészettudományi Karának posztgraduális képzésén részt vevó romológia szakos hallgatói, illetve a tanszék cigány származású oktatói, munkatársai voltak. Tólük újabb rokon, ismerôs, barát (cigány és értelmiségi) elérhetôségét kaptam meg, akiket felkeresve ismét kaptam címeket, telefonszámokat, neveket.

Fontosnak tartottam a személyes kapcsolat kiépítését, ezért a válaszadók többségével személyesen is találkoztam.

Kutatásomat egy általam összeállított kérdóívvel s négy, mentális állapot mérésére használatos pszichológiai teszttel, skálával végeztem. Az általam összeállított kérdóív 31 kérdést tartalmaz, melyekból 13 zárt, 11 nyitott, 7 pedig zárt kérdéssel kombinált nyitott kérdés. A zárt kérdések a szociológiai háttérváltozókra irányulnak (nem, életkor, lakóhely, családi állapot, életkörülmény, születési hely és jelenlegi lakóhely közötti távolság, egészségi állapot, káros szenvedélyek, sportolás, családi, rokoni, baráti kapcsolatok intenzitása, találkozások gyakorisága, civil szervezetben, egyesületben való aktivitás, elégedettségi skála). A kombinált megoldást általában kapcsolatok minósítésének kifejtésére (pl. munkahelyi), s egyértelmúen megválaszolható, de bóvebben leírva árnyaltabb választ biztosító kérdéseknél alkalmaztam (pl. a kisebbségi létból fakadó hátrányok, küldetéstudat leírása). A nyitott kérdéseket az általam leginkább preferált kérdések körére hagytam; az értelmiségivé válás motivációira, a cigány és a nem cigány környezet reakcióira.

A mentális státus felméréséhez a következó skálákat használtam:

1. Beck-féle depresszió skála (BDI), melynek Kopp Mária és Skrabski Árpád által kifejlesztett rövidített változatát használtam (Kopp és Skrabski 1995).

2. Crumbaugh \& Maholick (1964) életcél-kérdôiv rövidített változata (Kopp és Skrabski 1995): általánosan használt mentális állapotmérổ kérdôív.

3. Juhász-féle neurózis pontozó skála (Juhász és mtsai 1978) a neurózis tüneti vizsgálatára.

4. Cadwell-féle szociális támogatás kérdôí Kopp és Skrabski által hazai viszonyokra adaptált változata (Kopp és Skrabski 1995). 


\section{EREDMÉNYEK}

A kutatásban részt vevô diplomások közül 29 nó, 22 férfi, az átlagéletkor 40 év. A nem szerinti megoszlás azt mutatja, hogy a fiatalabb és az idősebb korosztályban lényegesen több a nő, a középkorúak között pedig kis mértékben a férfiak felülreprezentáltak (1. ábra). (Egy nói válaszadó nem adta meg az életkorát.)

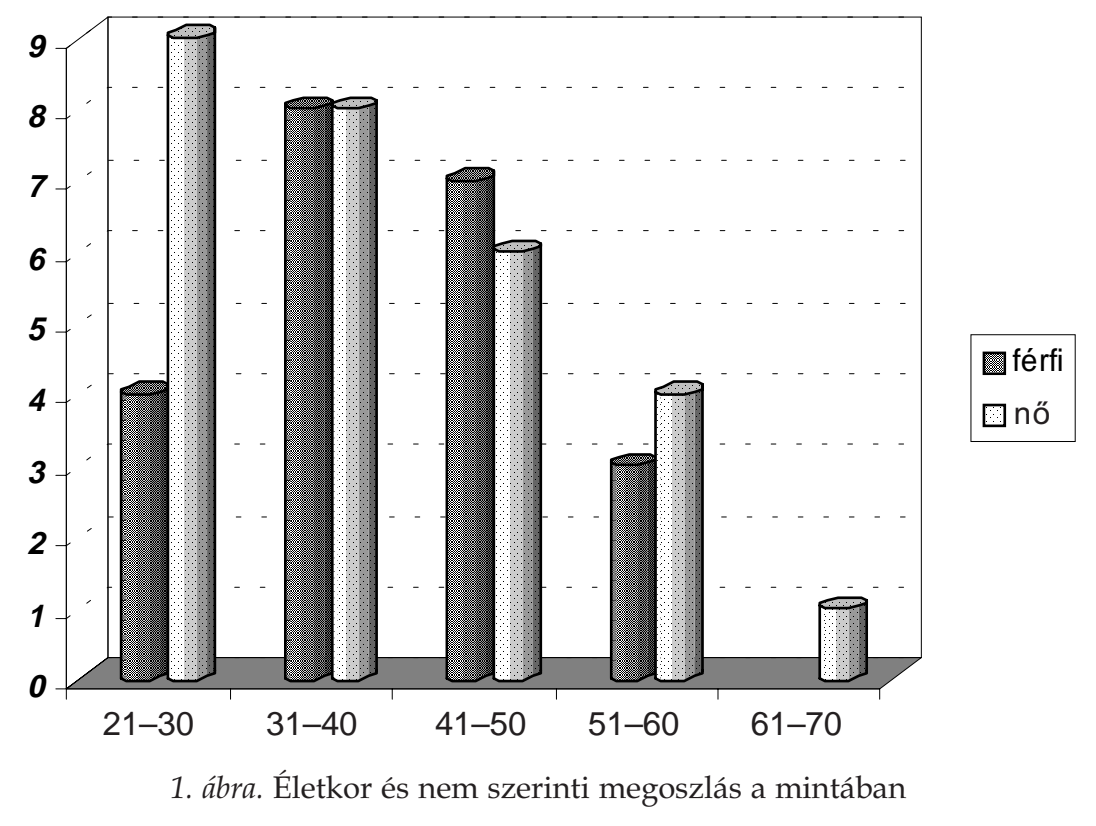

Családi állapotukat tekintve házasságban él a férfiak és a nók fele, s gyakorlatilag egyforma az elváltak aránya is. Míg a férfiak $36 \%$-a él egyedül, a nóknél csupán 21\% ez az arány, s 14\%-uk élettársi kapcsolatban él. A férfiak közül senki nem jelzett házasság nélküli együttélést. A településnagyság és a családi állapot közötti viszonyt vizsgálva leginkább feltû́nó, hogy a falun élố nốk mind házasok, míg az élettársi kapcsolatot választók kizárólag a fóvárosban élnek. Az elsó diplomát túlnyomó többségük a rendszerváltás után szerezte (2. ábra; két fó nem adta meg diplomaszerzési életkorát).

Az első diploma megszerzésekor betöltött életkor jelentősen eltér a nem cigány fiatalok diplomaszerzési életkorától (1. táblázat). 


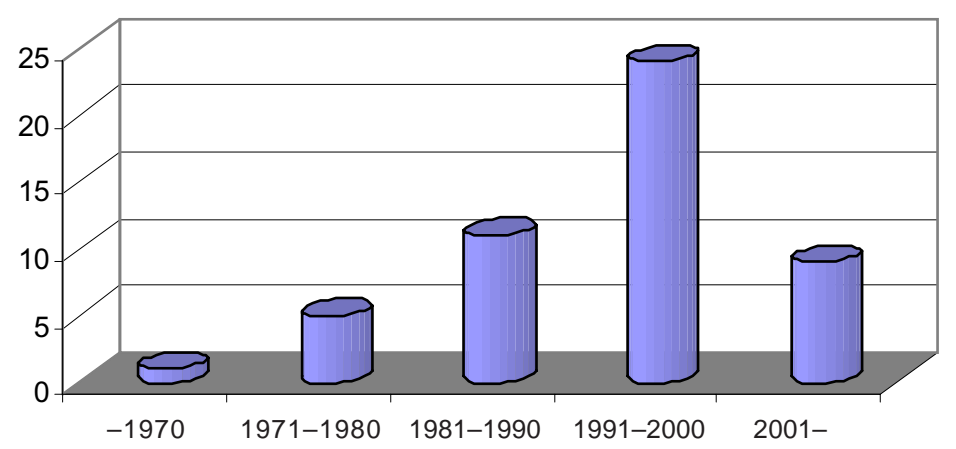

2. ábra. A mintában szereplők diplomaszerzésének időpontja

Az adatokból következtetni lehet arra, hogy a mintában szereplő diplomások nem egyenes ívú tanulmányi pályát futottak be, hanem „kerüló" úton jutottak el az egyetemekre, fóiskolákra, munka, sok esetben már család mellett végezték tanulmányaikat

A kérdőívre válaszolók lakóhely szerinti megoszlása: 33\%-uk a fóvárosban lakik, 29\% nagyvárosi, 22\% kisvárosi, 16\%-uk pedig falun él.

Arra a kérdésre, hogy rajtuk kívül van-e más diplomás is a családban, $69 \%$ válaszolt igennel. Az "igen” válaszokat $(\mathrm{n}=35)$ megvizsgálva - hiszen azt is kértem, jelöljék ",ki” a diplomást - az alábbi eredményt kaptam (a válaszadók több diplomást is megjelölhettek):

- családjuk felmenó ágában ketten jelöltek diplomás szülót (mindkét esetben az apát), ketten pedig nagynénit, nagybácsit;

- oldalági rokonságban 30-an jeleztek felsófokú végzettséggel rendelkező rokont: négyen feleséget, férjet; huszonöten testvért, unokatestvért, sógort;

1. táblázat. Az elsô diploma megszerzésekor betöltött életkor a minta szereplói között

\begin{tabular}{|c|c|}
\hline $\begin{array}{c}\text { Az első diploma megszerzéskor } \\
\text { betöltött életkor }\end{array}$ & $\begin{array}{c}\text { A diplomázottak száma } \\
\text { és aránya }(\mathrm{n}=49)\end{array}$ \\
\hline $19-22$ év & $11(22 \%)$ \\
\hline $23-26$ év & $13(27 \%)$ \\
\hline $27-30$ év & $7(14 \%)$ \\
\hline $31-34$ év & $5(10 \%)$ \\
\hline $35-38$ év & $6(12 \%)$ \\
\hline $39-42$ év & $4(8 \%)$ \\
\hline $43-46$ év & $2(4 \%)$ \\
\hline 48 év & $1(2 \%)$ \\
\hline
\end{tabular}


- lemenó ágban 3 válaszadó jelzett saját diplomás gyermeket.

A kapott eredmények azt mutatják, hogy a mintában szereplók elsó generációs értelmiségiek, hiszen csak a minta két tagja rendelkezik diplomás szülóvel.

E két - már második generációs értelmiségi - válaszadó adatait elemezve azt találtam, hogy mindkettő fiatal (27, illetve 30 éves), egyedülálló nó, a fővárosban élnek, szüleik is itt laknak. Mért mentális státusuk alapján mentálisan egészségesek, kiegyensúlyozottak, pozitív életcéllal, nagy társas, szociális támogatottsággal rendelkeznek, kisebbségi létükból hátrányt nem tapasztaltak, a cigányság felé küldetéstudatot éreznek. Egyikük intézményvezető, másik média-szakember.

Életkörülményeit a válaszadók ( $n=50$; egy személy nem válaszolt e kérdésre) többsége átlagosnak ítélte, 4\%-uk átlag feletti, 8\%-uk pedig átlag alatti körülményeket jelzett. A helyzetét átlag felettinek minósító két válaszadó közül az egyik a mintában szereplő legidősebb tag: 70 éves, fôvárosi, házasságban élő, nyugdíjas tanárnô. A másik, átlagon felüli körülményekkel rendelkező: 49 éves, házas, nagyvárosban élő férfi. Végzettségét, foglalkozását nem adta meg. Elsô diplomáját az átlaghoz hasonlóan, aránylag késón, 30 éves korában szerezte meg. Az átlag alatti életkörülményeket jelölő négy diplomás közül 1 nó, 3 férfi. Egy férfi falun él, egyedülálló, még agrármérnökként dolgozik, de válaszaiból a munkanélküliségtôl való félelme olvasható ki. A többi válaszadó pedagógus végzettségú, s mindhárman messze költöztek a szülóhelyüktól.

A szülóhely és a jelenlegi lakóhely közötti távolságot azért vizsgáltam, mert feltételeztem, hogy aki messzire költözik a szülóhelyétól, az a családi-rokoni kapcsolatait nehezebben tudja ápolni, emiatt kevésbé vagy egyáltalán nem részesül a közösség támogató, védelmet nyújtó erejében. A kérdőívet kitöltók nagyfokú mobilitását mutatja, hogy 65 százalékuknál a szülóhely és a jelenlegi lakóhely nem egyezik. A messzire költözók aránya $40 \%$. A legnagyobb mozgás a fóváros felé irányul; a messzire költözók 60\%-a Budapestet választja lakóhelyül, s az összes elköltözött között is $39 \%$ a fóvárosban letelepülók aránya. Szülóhelyéhez közel lakik a válaszadók $25 \%$-a, s nem költözött el 35\%. A mintában a két nem „vándorlási” magatartása nagy különbséget mutat, amint az a 2. táblázatból leolvasható. 
2. táblázat. Szülőhely és jelenlegi lakóhely közötti távolság a vizsgált mintában

\begin{tabular}{|l|c|c|c|}
\hline Nem & Nincs távolság & $\begin{array}{c}\text { Szüleihez közel } \\
\text { költözött }\end{array}$ & Messzire költözött \\
\hline Nó $(\mathrm{n}=29)$ & $15(52 \%)$ & $6(21 \%)$ & $8(28 \%)$ \\
\hline Férfi $(\mathrm{n}=22)$ & $3(14 \%)$ & $7(32 \%)$ & $12(55 \%)$ \\
\hline Összes $(\mathrm{n}=51)$ & $18(35 \%)$ & $13(25 \%)$ & $20(40 \%)$ \\
\hline
\end{tabular}

A nók 52\%-a nem költözött el szülóhelyéról, s az elköltözók $21 \%$-a is közeli településen lakik. Ezzel szemben a férfiak 55\%-a messzire költözött, s csupán 14\%-uk él ott, ahol született.

Az egészségi állapot önminősítése igen fontos, hiszen minden szưrővizsgálatnál pontosabb előrejelzóje a halálozásnak (Skrabski és mtsai 2004). A vizsgált minta $63 \%$-a átlagosnak, 20\%-a kiválónak, 17\%-uk pedig rossznak ítélte egészségi állapotát. A magukat átlagos egészségi állapotúnak minôsítók közül azonban sokan jelezték, hogy krónikus, illetve egyéb betegségük, magas vérnyomásuk, vércukor-problémájuk van. A felsorolt panaszokat is figyelembe véve így már a válaszadók 39\%-a tekinthetó betegnek. (Elgondolkodtató, vajon miért ítélik e komoly betegségek fennállása mellett is átlagosnak az egészségi állapotukat a válaszolók?)

Szembetûnó különbséget találtam a két nem egészségi állapota között: a megromlott egészségi állapotúak $74 \%$-a nő, a kiváló egészségnek örvendôk (magukat annak minősítők) 80\%-a pedig férfi! (Meg kell jegyeznem, hogy a kutatásba bekerült mindkét nem átlagéletkora - teljesen véletlenszerúen - 40 év.)

A káros szenvedélyek tekintetében az alacsony alkoholfogyasztás - ami a cigányságra általánosan is jellemzó - a vizsgált mintámban is beigazolódott: az 51 válaszadó $22 \%$-a absztinens, soha nem fogyaszt alkoholt, 69\% csak ritkán, mindössze 19\%-uk hetente, s 4\% naponta iszik szeszes italt. A dohányzás terén rosszabb az arány: $47 \%$ dohányzik, s ezen belül 20\%-uk erôs dohányos.

A rendszeres testedzés, sportolás igen ritka (4\%), s heti 1-2 alkalommal is csak a válaszadók $14 \%$-a mozog.

A családi kapcsolatok intenzitásának mérése azt mutatta, hogy egy kivétellel minden válaszadó ápolja a kapcsolatot családjával, viszont rokonokkal már csak $64 \%$-uk. A messzire költözöttek $47 \%$-a, a helyben, illetve a szülóhelyhez közel élóknek pedig 32\%-a nem tartja a rokonaival a kapcsolatot. A kapcsolattartás leggyakoribb formája a napi találkozás, valamint a hétvégi látogatás. Egyetlen személyt találtam a mintában, aki mind rokonaival, mind szúkebb családjával megszakította a kapcsolatát.

Munkahelyi kapcsolataikat a válaszadók 70\%-a jónak, ezen kívül 15\%uk nagyon jónak minósítette. Ezt a képet azonban befolyásolja az is, hogy 
a megkérdezettek jelentôs része cigány alapítványnál, cigány iskolában, cigány újságnál, cigány önkormányzatnál dolgozik, cigány munkatársaktól körülvéve. Nem egy esetben a válaszadók maguk az igazgatók, munkahelyi vezetôk voltak.

A rossz (11\%) és nagyon rossz (4\%) munkahelyi kapcsolatot jelzók közül néhányan röviden leírták rossz közérzetük okát:

- "kirekesztés miatt” (36 éves, nagyvárosi diplomás férfi)

- "félnek tólem, nem értenek" (36 éves falusi tanár)

- „a körülmények miatt” (30 éves fóvárosi újságírónó)

- "2 éve hátrányos megkülönböztetés ér" (55 éves falusi tanítónó)

- "munkahelyemen hátrányosan megkülönböztetnek” (35 éves fővárosi pedagógusnó).

Baráti kapcsolatok fenntartását a többség fontosnak tartja, a válaszadóknak csak 8\%-a nem ápol barátságot. A barátok számát néhányan nem számmal jelezték, hanem a "sok” szóval írták le. Általában 0-5, illetve 10-20 számhatárok közötti számokat adtak meg, s volt, aki 180-at, illetve 42-t jelzett. A barátok számára vonatkozó kérdésre csak 42-en írtak számot, ezt elemezve nem találtam lényeges különbséget a szülóhelyén, illetve ahhoz közelben élók és a messzire költözöttek barátainak száma között. Az átlagos „barátszám” 8,25, illetve 8,52.

Civil szervezetnek, egyesületnek, alapítványnak a válaszoló cigány értelmiség 70\%-a tagja.

A hátrányos megkülönböztetés múltbeli vizsgálata azt mutatja, hogy 31-en (61\%) átéltek kisebbségükból fakadó megkülönböztetett bánásmódot, 39\%-uk viszont nem tapasztalt diszkriminációt.

Az óket ért hátrányos megkülönböztetést legtöbben csak jelölik, kimagaslóan sok az egyszavas, egy-két szavas válasz, pl. „iskola, szerelem, munkahely", "szidtak”, „kiközösítés", „gúnyoltak”, ,a boltban”, ,gyerekcsúfolás".

Akik bővebben válaszoltak, az alábbiakat írták:

- "munkahelykeresés, vezetốválasztás idején hátrányosan kezeltek”

- "jogaimban korlátoztak"

- "nem engedtek be szórakozóhelyekre"

- "jól tanít, de miért nem változtat a nevén"

- "lekezelő bánásmód, pl. orvosi rendelóben"

- "kiközösítés gimnáziumban, késóbb munkahelyen"

- "gazdasági és társadalmi elóitélet"

- "iskolában a tanár negatívan megkülönböztetett”

- "általános iskolában osztálytársaim és iskolatársaim naponta csúfoltak származásom miatt" 
- „nôgyógyászati vizsgálaton lekezelő bánásmód, sértô hang, nem alapos vizsgálat, aminek eredménye súlyos szövódmény lett"

- "közértben biztonsági ôr kísér feltûnô távolságból"

- "munkahelyi jutalmat nem kaptam"

- "vezetốválasztásnál, bár én voltam az esélyes, nem engem választottak"

- "át akartak verni"

- "éreztették velem: nehogy már egy cigány mondja meg...."

- "a buszon nem ültek mellém”

Azok közül, akik hátrányos megkülönböztetést nem tapasztaltak, néhányan megjegyezték, hogy valószínúleg azért nem éri óket elóítéletes bánásmód, mert nem viselnek kifejezett rasszjegyeket.

A környezetük jelenlegi hátrányos megkülönböztető magatartására kérdezve, lényegesen változott az arány. Ma hátrányt tapasztal kisebbségi léte miatt a válaszadók 44\%-a, 56\%-uk semmiféle megkülönböztetést nem érez (3. táblázat).

3. táblázat. A megkülönböztetés alakulása a múltban és a jelenben

\begin{tabular}{|l|c|c|}
\hline & A múltban $(\mathrm{n}=51)$ & A jelenben $(\mathrm{n}=50)$ \\
\hline $\begin{array}{l}\text { Hátrányos megkülönböztetést } \\
\text { tapasztalt }\end{array}$ & $31(61 \%)$ & $22(44 \%)$ \\
\hline $\begin{array}{l}\text { Hátrányos megkülönböztetést } \\
\text { nem tapasztalt }\end{array}$ & $20(39 \%)$ & $28(56 \%)$ \\
\hline
\end{tabular}

A kedvező változás ellenére két esetben találtam negatív irányú változást; amikor a múltban nem tapasztaltak megkülönböztetést, a jelenben viszont igen. Az egyik esetben 41 éves, falun éló férfi - mint írja - most azért él át megkülönböztetést, mert falujában a cigányság érdekeinek a képviselójévé választották, s emiatt naponta találkozik az elóítéletes magatartással. A másik, megkülönböztetést a múltban nem, csak a jelenben tapasztaló válaszadó 46 éves, nagyvárosban éló diplomás nó, aki hat éve munkanélküli, s úgy véli, ennek cigány származása az oka.

A diploma, a felsófokú végzettség megszerzését motiváló személyek közül a család, a szülók szerepét emelték ki a legtöbben (56\%), óket követték a tanítók, tanárok (23\%), és sokan (26\%) megemlítették még tanítójukat, tanárukat is a szülók mellett. A munkahely, környezet, barátok elsődleges motiváló szerepét 7\% jelölte. A vizsgálatban résztvevók 14\%-a senkitól nem kapott segítséget, csak magára számíthatott. Motiváló tényezôként néhányan kiemelték a gimnáziumi közösség és nem cigány diplomás barátaik inspiráló szerepét (3. ábra). 


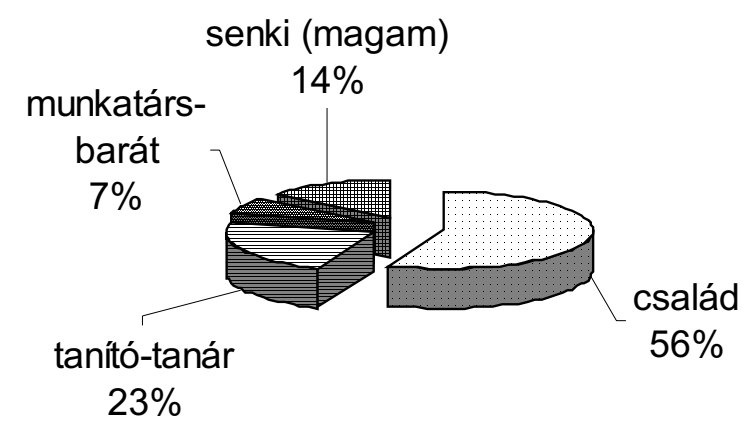

3. ábra. A mintában szereplók továbbtanulását motiváló személyek aránya

A cigány származású elsố generációs értelmiség szempontjából különös jelentôségú a környezet reagálása. A nem cigány közösség reakciói a válaszadók $(\mathrm{n}=45)$ szerint a következók voltak:

- meglepödnek, csodálkoznak (6) "Jé, hát ilyen is van?"

- örül (6)

- elfogadja (8)

- tiszteletet, elismerést kap környezetétól (12)

- vegyes fogadtatás (5)

- furcsának tartják (1)

- nem jól fogadnak (2)

- irigykednek (3)

Erre a kérdésre ketten azt válaszolták, hogy nem érdekli óket a környezet reagálása.

A nem cigány környezet reakcióit néhányan bővebben is megfogalmazták:

- „elfogadják a végzettségemet, de a többségnek velem szemben mindig fenntartásai vannak"

- "tisztelnek, de állandóan bizonyítanom kell, ami dühöt vált ki belólem"

- "tisztelnek, de nem tudnak mit kezdeni vele"

- "tisztelnek, de a szúkebb baráti körbe nem vesznek be"

- "általában elfogadnak, de van, aki azt mondja, jó nekem ott, ahonnan jöttem"

- "a magyaroknak nagyon cigány vagyok"

- "megette óket a guta" (ez a válaszadó ugyanezt írta a cigány környezet fogadtatásához is)

A nem cigány környezet reakcióit mutatja a 4. ábra.

A cigány környezetnek a saját diplomásaival kapcsolatos reakciói nagyon változatosak. Teljesen pozitív választ a válaszadó mintából $(\mathrm{n}=44)$ 30 fó (68\%) adott. E pozitív reakciók a következók: 


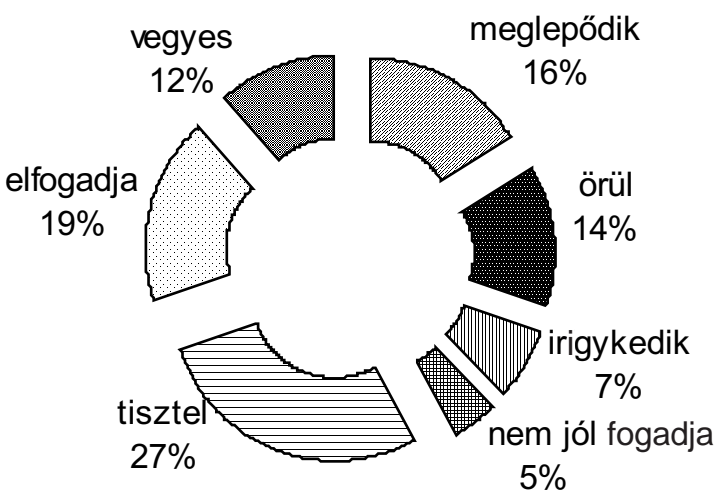

4. ábra. A nem cigány környezet reakciói a diplomás cigány emberrel kapcsolatban

- örülnek (6)

- példakép vagyok, felnéznek rám (5)

- tisztelnek (14)

- természetesnek tartják

- elfogadják (2)

További 9 válaszadó (20\%) vegyes fogadtatásról ír: „örülnek, de...”, "büszkék rám, de....":

- "már valahogy nem éreznek közéjük valónak, s ez rossz"

- "a szüleim büszkék rám, de a rokonaim megvetnek, mert »más "lettem"

- "a cigányoknak a tanultságom miatt nem vagyok cigány"

- "van, aki azt mondja, minek ennyit tanulni egy cigány lánynak"

- "örülnek, de van, aki a hátam mögött irigykedik"

- "örül a szúkebb család, de a rokonaim lenéznek: minek kellett ez neked?"

- "örülnek, gratuláltak, de úgy érzem, "kívülálló" lettem”

- "tisztelnek, de néha azt hiszik, már nem tartozom közéjük, beképzelt vagyok stb., pedig én is roma lány vagyok"

Ketten azt írták, hogy környezetük furcsának tekinti óket:

- „elfogadják, de furcsállják"

- "elfogadják, de nem teljesen értik".

Egyértelmú negatív hozzáállásról - irigykedésról - három válaszadó írt.

A cigány környezet viszonyát értelmiségivé vált rokonukhoz, ismerôsükhöz, családtagjukhoz az 5. ábra mutatja.

Az ábráról leolvasható, hogy a válaszadók szerint a cigány közösség nagy része pozitívan fogadja a felsőfokú végzettségúeket; $68 \%$-uk teljes elfogadást tapasztalt (tisztel, örül, elfogadja, természetesnek tartja, felnéznek rá), 20\%-uk vegyes fogadtatást észlel, 5\%-ukat furcsának tartják, csak negatív hozzáállást 7\%-uk tapasztalt. 


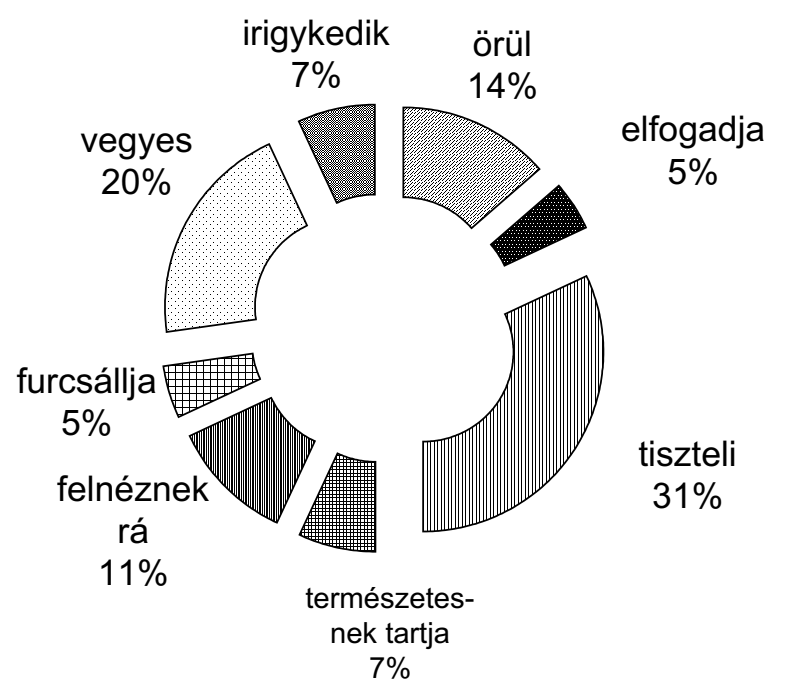

5. ábra. A cigány környezet reakciói a cigány diplomás emberrel kapcsolatban

Összehasonlítva a nem cigány és a cigány környezet cigány diplomásokkal kapcsolatos reakcióit, a következó eredményt kapjuk (4. táblázat).

4. táblázat. A nem cigány és a cigány környezet reakciói a cigány származású diplomásokkal kapcsolatban

\begin{tabular}{|l|c|c|}
\hline & $\begin{array}{c}\text { A nem cigány környezet } \\
\text { reakciói }(\mathrm{n}=43)\end{array}$ & $\begin{array}{c}\text { A cigány környezet } \\
\text { reakciói }(\mathrm{n}=44)\end{array}$ \\
\hline $\begin{array}{l}\text { Pozitív reakció } \\
\text { (öröm, tisztelet stb.) }\end{array}$ & $26(60 \%)$ & $30(68 \%)$ \\
\hline Vegyes fogadtatás & $5(12 \%)$ & $9(20 \%)$ \\
\hline Értetlenül, furcsán fogadja & $7(16 \%)$ & $2(5 \%)$ \\
\hline $\begin{array}{l}\text { Negatív reakció } \\
\text { (irigykedés, elutasítás) }\end{array}$ & $5(12 \%)$ & $3(7 \%)$ \\
\hline
\end{tabular}

A cigány és a nem cigány környezet túlnyomó többsége pozitívan viszonyul a diplomás cigány emberekhez. Mindkét környezetben vannak irigykedók, elutasító magatartást tanúsítók, s ezek aránya nagyobb a nem cigány közösségben. A nem cigány környezet inkább meglepődik, furcsállja, ha egy cigány ember diplomás lesz, a cigány környezetben viszont magasabb a vegyes fogadtatás aránya, ami a tágabb rokonság elutasító magatartását jelzi.

Az adatok azt mutatják, hogy a többségi társadalom $40 \%$-a, a kisebbség 32\%-a még nem tudja teljes örömmel, megbecsüléssel fogadni azokat 
az embereket, akik a társadalom pereméról, halmozottan hátrányos helyzetból indulva, igen nagy nehézségek árán, sokszor minimális támogatással eljutottak az értelmiségi rétegbe.

Valószínúleg ez is közrejátszik abban, hogy a megkérdezettek 24\%-a (!) válaszolta, hogy diplomája hátrányt jelent az életében.

A diplomássá válás hátrányát a következôképpen fogalmazták meg:

- "nem vesznek fel, mert az alacsonyabb végzettségúeknek kevesebb bért kell fizetni" (50 éves, kisvárosi tanárnó)

- "nem a képesitésemnek megfeleló munkát kapok" (53 éves, nagyvárosi pedagógusnó)

- "elszigetelódtem, régen boldogabb voltam, környezetemben nem fogadják szívesen a cigány értelmiségit" (46 éves, nagyvárosi munkanélküli diplomás nô)

- "amíg középfokú végzettségú voltam, addig volt perspektívám, ma nincs" (39 éves, kisvárosi pedagógusnó)

- "a magyarok irigykednek, mert a cigányból "valaki" lett, a cigányok pedig csak a fizikai munkát tekintik munkának, amit én csinálok, azt nem" (55 éves, falusi pedagógusnó)

- "a cigányok kirekesztenek” (29 éves, kisvárosi köztisztviselónó)

- „annyi, hogy ettól messzebb kerülsz a gyökereidtól (szokások, hagyományok, kultúra). Nehéz a romák köréból barátokat, társat találni. »Valami között« vagyunk." (27 éves, fővárosi intézményvezetô nó)

- "nem becsülik meg ma a tudást" (47 éves, falusi üzemmérnök férfi)

A kérdőívben mérni kívántam a válaszadók elégedettségi szintjének az alakulását a felsófokú tanulmányok végzésének az idejétól a jelen állapotig. A mérésre 7 fokú skálát használtam. A jelenlegi elégedettségi átlag értéke 5, de a kérdôíveket egyenként átvizsgálva a válaszadók elégedettsége között óriási különbségek vannak.

Elemeztem a legelégedettebb (7-es) és a legalacsonyabb (1-es) minôsítést adók adatait 13 paraméter alapján (nem, életkor, lakóhely, munkahelyi kapcsolat, jelenben tapasztalt hátrányos megkülönböztetés, baráti kapcsolatok, civil szervezeti tagság, küldetéstudat, életcél, társas támogatottság, jelenlegi foglalkozás). A szubjektív minósítés mellett a Juhászféle neurózis skála és a Beck-féle depresszió skála objektív minôsítését is figyelembe vettem.

Megelégedettnek, boldognak értékelte jelenlegi helyzetét az e kérdésre válaszolók $(n=45) 20 \%$-a, azaz 9 fó. A kilenc egyéni adatot feldolgozva és összevetve azt találtam, hogy az átlagéletkoruk 46 év (ebbe a csoportba került a minta legidósebb, 70 éves válaszadója is); nemi megoszlásuk 5 férfi és 4 nó, lakóhely szerint nincs közöttük jelentôs különbség, a 
fôváros-nagyváros-kisváros-falu megoszlás: 2-2-3-2. Családi állapotukat tekintve egy elvált, s egy fiatal, még egyedülálló van közöttük, a többiek mind házasságban élnek. Foglalkozásukat néhányan nem jelölték, aki feltüntette: nyugdíjas tanárnó, szerkesztô-riporternó, óvónó, református lelkész, intézményigazgató.

Közösnek találtam az elégedett válaszadók körében a következóket:

- egy kivételével mindegyikük tagja valamilyen civil szervezetnek, egyesületnek;

- mindannyian kiterjedt baráti kapcsolatot ápolnak;

- társas, szociális támogatottságuk megfelelő;

- egy kivételével mindannyian éreznek küldetéstudatot a cigányság felé, s ennek megfelelóen tevékenykednek is;

- munkahelyi kapcsolatukat 57\%-uk nagyon jónak, 43\%-uk pedig jónak minősítette;

- hátrányos megkülönböztetést jelen helyzetében csak egy személy érez, mióta a cigányság érdekeit hivatalosan képviseli;

- mindegyikük pozitív életcéllal rendelkezik, a Juhász-féle neurózis skála és a Beck-féle depresszió skála mérései alapján mentális egészségük megfeleló.

Boldogtalannak, csalódottnak ítélte jelenlegi állapotát a válaszadók 16\%-a, 4 nó és 3 férfi. Családi állapotuk az elégedettek csoportjától jelentôsen eltér: mindössze 57\%-uk él házasságban, 29\%-uk elvált, s 14\%-uk egyedülálló. Átlagéletkoruk 42 év. Lakóhely szerinti megoszlást tekintve fốvárosban, nagyvárosban él 71\%, kisvárosban, falun 29\%.

- munkahelyi kapcsolatait 43\% jónak, 29\% nagyon rossznak, 28\% rossznak ítélte;

- jelenleg hátrányos megkülönböztetést 89\%-uk tapasztal;

- baráti kapcsolatot többségük ápol, s két személy kivételével tagjai valamilyen civil szervezetnek;

- a szociális támogatottság a válaszadók felénél feltúnóen hiányos, annak ellenére, hogy baráti kapcsolataik vannak (nehéz élethelyzetben azonban minimális segítséget jeleztek barátaik részéról);

- ebbe a csoportba került a vizsgált minta egyetlen olyan tagja is, aki sem családi, sem rokoni kapcsolatokat nem ápol;

- küldetéstudattal - igen rossznak ítélt jelenlegi állapotuk ellenére mindegyikük rendelkezik, s tesz is a cigányság érdekében valamit (érdekképviselet, nyelvoktatás stb.);

- foglalkozást ebben a csoportban is többen nem jelöltek, a válaszadók többsége pedagógus, egy író és egy munkanélküli szerepel még ebben a csoportban; 
- a neurózis skála kezelést igénylő neurózist mutat 57\%-uknál, a Beckféle depresszió skála szerint pedig 57\%-uknál enyhe, 43\%-uknál pedig közepesen súlyos depressziós tünetegyüttes észlelhetó.

A múltban a mai helyzetét hasonlóan képzelte el a kérdóívet kitöltók $43 \%$-a, többségük azonban mást várt. A „mást” remélók 78\%-a jobb életfeltételekben, munkalehetőségben reménykedett:

- "azt hittem, hogy a rendszerváltozás után a romák élethelyzete és társadalmi pozíciói javulnak"

- "azt hittem, értékelik a tudást és a tapasztalatot, de tévedtem, a becsületesség, tisztesség, tudás nem érték ma az országban"

- "jobbnak képzeltem, de nem volt értelme tanulni"

- "nem számítottam ilyen mértékú előitéletekre"

- "nagyobb írói megbecsülést, külföldi megjelenést, dijat vártam volna"

- "sok a társadalmi igazságtalanság"

- "sokkal elóbb szerettem volna odajutni, ahol most vagyok"

- "azt gondoltam, hogy nem kell ilyen idôs korban is tanulnom azért, hogy úgy-ahogy megéljek"

- "azt hittem, szükség lesz a tudásomra"

- "nem cigány környezetem valahol még mindig csak a származásomat veszi figyelembe"

A mintában szereplók 22\%-a viszont el sem tudta képzelni, hogy ilyen jól alakul az élete:

- „az utóbbi évek lehetôségei sokkal nagyobbak, mint azt egy húsz évvel ezelôtt diplomát szerzett álmodhatta volna"

- „sokkal rosszabbnak képzeltem el"

- "nem tudtam elöre, hogy valamikor tanár leszek"

A segítségvárásról szóló kérdésre a kérdôívet kitöltóknek csupán 75\%-a válaszolt (38 fó), s a válaszok azt tükrözték, hogy a többség maga igyekszik megoldani a gondjait.

5. táblázat. A segítségvárás irányultsága

\begin{tabular}{|l|c|c|c|c|c|}
\hline & Senkitól & $\begin{array}{c}\text { Nem cigány } \\
\text { politikusoktól }\end{array}$ & $\begin{array}{c}\text { Cigány } \\
\text { politikusoktól }\end{array}$ & Munkatárstól & Istentól \\
\hline $\begin{array}{l}\text { Segítségvárás } \\
(\mathrm{n}=38)\end{array}$ & $22(58 \%)$ & $7(18 \%)$ & $3(8 \%)$ & $3(8 \%)$ & $3(8 \%)$ \\
\hline
\end{tabular}

A cigány és a nem cigány politikusok felé megfogalmazott kérések:

- "a kormányzattól szakmai alapú támogatási rendszert"

- "alapítványoktól kutatáshoz anyagi támogatást"

- "aktívabb állásfoglalást és iránymutatást"

- "hatékonyabb érdekképviseletet, a tudás értékelését" 
- „munkahelyet a vidéki roma értelmiségnek"

Küldetéstudatot saját kisebbsége felé a válaszadók 92\%-a érez, ennek megfelelően többféle tevékenységet végeznek. A válaszok között a következók szerepeltek:

- közösségi házban érdekképviseletet vállal;

- közéleti szerep, gyerekek motiválása a tanulásra;

- kutatómunkát végez (latens rasszizmus megnyilvánulása a romák felé);

- pályázatírás, hagyományőrzố tánccsoport vezetése;

- oktatás, tanítás;

- alapítványi munka;

- nyelvápolás, nyelvoktatás;

- kormányprogramban való részvétel;

- roma kultúra oktatása;

- információadás, pályázatírás;

- táboroztatás;

- életük megírása.

A küldetéstudat megvalósításában nagyon sokan kiemelik a becsületes, jól végzett munkát, amivel példát adnak a többi cigány embernek.

A válaszadók $8 \%$-a nem érez küldetéstudatot a cigányság felé, egyikük erre a kérdésre így válaszolt:

„Én már elváltam a fajtámtól. Teljesen asszimilálódtam a társadalomba. Engem már a szüleim is tudatosan így neveltek. A nyelvet sem tanitották meg, velem nem beszéltek cigányul otthon soha" (40 éves, nagyvárosi tanítónó).

A kutatásban résztvevők között végzettség szempontjából felülreprezentáltak a tanítói, tanári végzettségúek (32\%), óket követik a múvelódésszervezói (11\%), majd a szociális munkás, szociálpolitikusi, szociálpedagógusi diplomával rendelkezók. A mintában szerepel fizikus, agrármérnök, mérnök, nyelvész, teológus, hittanár, menedzser, óvónő és jogász végzettségú diplomás is.

Jelenlegi foglalkozásukat tekintve:

- pedagógusként dolgozik $30 \%$,

- igazgató, intézményvezetô (elsősorban alapítványok, civil szervezetek vezetói) $16 \%$,

- médiában dolgozik (újságíró, titkár, szerkesztố riporter) 11\%,

- munkanélküli 5\%,

- egyéb 38\% (író, egyetemi oktató, tudományos munkatárs, óvónó, református lelkész, minisztériumi fótanácsos, munkaerôpiaci szakreferens, hitoktató, nyelvtanár, szociális munkás).

A vizsgálati mintában szereplôk mentális állapotát négyféle kérdőívvel, illetve skálával mértem. 
A Crumbaugh \& Maholick életcél-kérdőív rövidített változatával mért mentális állapot a válaszadók 15\%-ában mutatott életcél hiányt. Az egyéni adatokat megvizsgálva az alábbiakat találtam:

- 71\%-uk nô;

- csupán 29\% él házasságban, a többiek elváltak vagy egyedülállók;

- átlagéletkoruk 43 év;

- 43\%-nak rossz az egészségi állapota (krónikus betegség, magas vérnyomás stb.);

- munkahelyi kapcsolatait 72\% jónak, 14\% nagyon rossznak ítélte, $14 \%$ pedig munkanélküli;

- szociális támogatottságuk - annak ellenére, hogy baráti, családi kapcsolatok fenntartását, ápolását jelezték - 86\%-uk esetében igen hiányos (a szociális-támogatás kérdőív a nehéz élethelyzetekben várható segítségekre kérdez, a kapcsolatok mélységét jól mutatja);

- 29\%-nál kezelést igénylő neurózis észlelhető, Beck-féle depresszió skálával mérve pedig 57\%-uknál enyhe, 43\%-nál középsúlyos depressziós tünetegyüttes észlelhetô.

E rossz mentális állapot minden valószínúség szerint több tényezóból tevődik össze, kialakulásában a házasság és a párkapcsolat nyújtotta védófunkciók hiánya, a rossz egészségi állapot, a munkanélküliség, a szociális támogató kapcsolatok elégtelen volta egyaránt szerepet játszhat.

A kutatási mintában szereplók 58\%-ának a szociális támogatottsága megfeleló, $42 \%$-nak hiányos.

A Juhász-féle neurózis pontozó skálával mérve a válaszadók mentális állapotát ( $\mathrm{n}=49$; két válaszadó nem töltötte ki a mentális státust méró teszteket) az látható, hogy neurózis szempontjából veszélyeztetett (7 pont fölötti értéket mutató) 12\%, már kezelést igénylő (10 pont fölötti értéket mutató) $16 \%$. Az összes válaszadó közül tehát $28 \%$ neurózis szempontjából érintett (6. ábra).

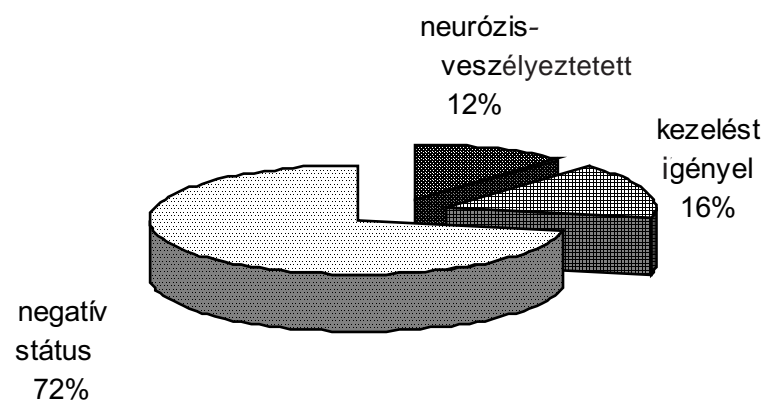

6. ábra. A mintában szereplók mentális státusa a Juhász-féle neurózis skálával mérve 


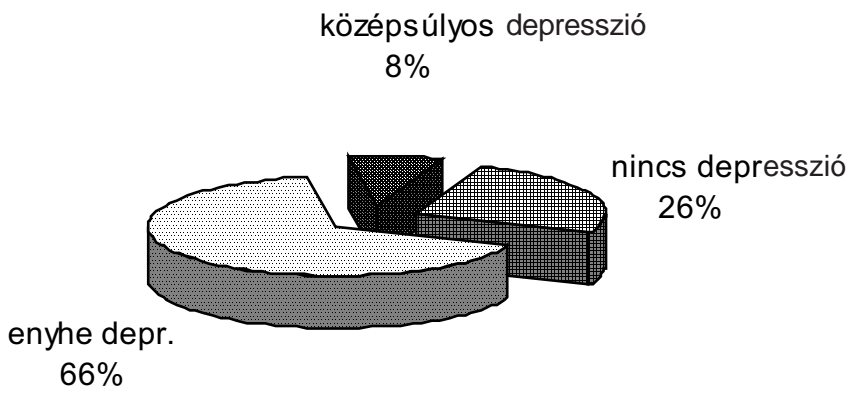

7. ábra. A mintában szereplók mentális státusa a Beck-féle depresszió skálával mérve

A Beck-féle depresszió skála alapján a vizsgálatban szerepló cigány értelmiségiek mentális státusát a 7. ábra mutatja.

A kapott eredmények szerint a mintában szereplók 66\%-a enyhe, 8\%uk pedig középsúlyos depressziós tünetegyüttest mutat.

Összesítve a Juhász-féle neurózis skála és a Beck-féle depresszió skála eredményeit, látható, hogy a cigány értelmiség mintában szereplő tagjainak $(n=49) 76 \%$-a nem kielégító mentális státussal rendelkezik; 37 válaszadónál neurózis és/vagy depressziós tünetegyüttes enyhébb, illetve súlyosabb formája mérhetố.

\section{MEGBESZÉLÉS}

\section{A külsố segítố szerepe}

A vizsgálat során kapott eredményeim azt mutatják, hogy

- a válaszadók 56\%-a az értelmiségivé váláshoz, a diploma megszerzéséhez a legtöbb motivációt a családtól kapta;

- a válaszadók 23\%-a jelezte, hogy a legtöbb motivációt tanítóitól, tanáraitól kapta a továbbtanulásra;

- további $26 \%$ a család szerepe mellett fontosnak tartotta kiemelni a pedagógusoktól kapott támogatást, ösztönzést;

- 7\%-uk baráti, munkahelyi motiválást tüntetett fel;

- 14\% azt írta, hogy senki nem motiválta, magától kezdett el tanulni.

Várakozásaimmal szemben tehát a külsó motiváló eró (30\%) mellett a család ösztönzó ereje a meghatározóbb, jelentősebb (56\%). Ez az eredmény azért is különösen figyelemre méltó, mert mindössze két személy jelezte, hogy felmenói között diplomás rokon van (mindkét esetben az apa). Úgy túnik tehát, hogy a cigány családok, cigány szülók egy része (sokszor dacolva a rokonok értetlen, elítéló megnyilvánulásaival) felismer- 
ték a diplomaszerzés fontosságát, s egyre inkább ösztönzik, támogatják gyermekeiket a továbbtanulásban. Ugyanakkor nagy szerepük van a pedagógusoknak is, hisz a válaszadók csaknem fele (23\% elsődlegesen, $26 \%$ másodlagosan) kiemelte óket.

\section{A diploma ára}

Vizsgálatom megkezdése elótt feltételeztem, hogy az értelmiségivé válásért a cigány embereknek - a hátrányos indulás, a többségi társadalom előítéletes magatartása, az elsőgenerációs nehézségek, a cigány értelmiségi minta hiánya, a társadalom "diplomás-telítettsége” miatt - súlyos árat kell fizetni, a kialakuló mentális állapotváltozások mérhetók lesznek.

A mentális állapot mérésére a már ismertetett skálákat, kérdóíveket használtam. Az eredmények azt mutatják, hogy a mintában szerepló cigány értelmiség

- 76\%-a nem kielégítô mentális státusú;

- 28\%-a neurózis szempontjából érintett (12\% veszélyeztetett, 16\% kezelést igényel);

- 66\% enyhe depressziós tünetegyüttest mutat, 8\% középsúlyos tünetegyüttestól szenved (vitális kimerültség, alvászavar, döntési nehézség, önhibáztatás, elégedetlenség, kilátástalanság stb.).

A nem megfeleló mentális állapot mellett a már manifesztálódott tünetek, betegségek is mutatják e populáció egészségesnek egyáltalán nem mondható állapotát; 39\%-nál kimutatható betegség (magas vérnyomás, vércukor-problémák, gyomortünetek, krónikus megbetegedések), melyek közül egyes megbetegedések (pl. a magas vérnyomás, gyomortünetek) talán kapcsolatban állhatnak a nagyfokú pszichés megterheléssel, stresszel, túlkompenzálással, elfojtással. A dohányzás - mint stresszkezeló magatartási mód - magas elófordulási aránya (40\%, ezen belül $20 \%$ erős dohányos) szintén utal a vizsgálatban résztvevők feszültségeire.

A kapott eredmények igazolták hipotézisemet: az értelmiségi státus eléréséért a cigány embereknek nagy árat kell fizetniük.

\section{A lakóhely és a szociális védóháló, támogatottság alakulása}

Feltételezésemnek megfelelóen a diplomásoknak csak kisebb része (35\%) marad szülóhelyén, többségük (65\%) elköltözik. Az elköltözók 40\%-a szülóhelyétól messze telepszik le. 
A kutatásomban szereplók szociális támogatottsága 57\%-ban megfelelô, 43\%-nál hiányos. Elemezve a szülóhelyen maradók, illetve a szülóhelyról elköltözók szociális támogatottságát, a 6. táblázatban szerepló adatokat kaptam.

A táblázat jól mutatja, hogy a szülóhelyükön élók körében jóval nagyobb mértékú a szociális támogatottság, mint az elköltözők között. Elgondolkodtató azonban, hogy az otthon maradottak körében is $22 \%$-os a támogatottság hiánya. Vajon a tradicionális családszerkezet felbomlása következtében kialakuló hiányt mutatja ez az adat? Biztató azonban, hogy a szülóhelyükról elköltözók 45\%-a új lakóhelyén megfelelô szociális támogató rendszert, közösséget talált, illetve épített ki.

6. táblázat. A szociális támogatottság és a szülóhelytôl való távolság kapcsolata

\begin{tabular}{|l|c|c|}
\hline Szülőhelytől való távolság & $\begin{array}{c}\text { Szociális támogatottság } \\
\text { megfelelő }\end{array}$ & $\begin{array}{c}\text { Szociális támogatottság } \\
\text { hiányos }\end{array}$ \\
\hline Nincs távolság $(\mathrm{n}=18)$ & $14(78 \%)$ & $4(22 \%)$ \\
\hline Elköltözött $(\mathrm{n}=33)$ & $15(45 \%)$ & $18(55 \%)$ \\
\hline Összesen $(\mathrm{n}=51)$ & $29(57 \%)$ & $22(43 \%)$ \\
\hline
\end{tabular}

\section{A társas támogatottság mértékének hatása a mentális állapotra}

Feltevésemet részben már alátámasztja az elégedettség és az elégedetlenség összetevőinek vizsgálata:

- a jelenlegi helyzetük alapján önmagukat elégedettnek nyilvánítók ( $\mathrm{n}=9$ ) mindegyike kiterjedt baráti kapcsolatokat, jó társas, szociális támogatottságot jelzett, általában házasságban élnek, és mentális állapotuk mért mutatói is kiegyensúlyozott, egészséges státust mutatnak;

- a jelenlegi helyzetüket boldogtalannak, csalódottnak minósítók ( $\mathrm{n}=7$ ) felénél feltûnően hiányzik a szociális támogatottság, jelentôs részük elvált, illetve egyedülálló.

Összevetve a mintába került személyek társas támogatottságát saját mentális állapotukkal azt tapasztaltam, hogy a hiányos társas támogatottsággal rendelkezők mindegyikének rossz a mentális státusa! Azok körében, akik erre a kérdésre válaszoltak $(n=48) 28$ esetben megfeleló, 20 esetben pedig hiányos a támogatottság. A korreláció értéke a szociális támogatottság és a neurózis között: 0,42. A megfeleló társas támogatottságot nélkülöző 20 válaszadó esetében a mentális státusra vonatkozóan az alábbi eredményeket találtam: 
- enyhe depresszió: 17 fó (85\%),

- középsúlyos depresszió: 3 fó (15\%),

- neurózis veszélye: 3 fó (15\%),

- kezelésre szoruló neurózis: 7 fó (35\%).

Hipotézisem a vártnál nagyobb mértékben igazolódott: a társas támogatottsággal nem rendelkezóknél minden esetben kimutatható a depressziós tünetegyüttes enyhébb vagy súlyosabb formája és/vagy a neurózis veszélye, illetve kezelésre szoruló neurózis.

\section{A civil szervezetekben, egyesületekben, alapítványokban történó tevékenykedés énvédó szerepe}

Feltevésemet látszólag igazolják a magukat elégedettnek minôsítók adatai: egy kivételével mindegyikük dolgozik valamilyen civil, elsősorban a cigányság köré szerveződött egyesületben, alapítványban. A korrektebb kép érdekében azonban még összehasonlítottam a mentálisan jobb, illetve a mentálisan rosszabb státust mutatók civil szervezetben történó elköteleződését. A kérdőívet kitöltók 70\%-a jelezte, hogy tagja valamilyen civil szervezetnek, azaz a mentálisan rosszabb státussal rendelkezók nagy része is részt vesz civil munkában (de legalábbis tagja ilyen szervezetnek). A civil szervezetek védő hatására vonatkozó feltevésem tehát nem nyert igazolást.

\section{A nyitott kérdésekre adott válaszok}

A visszakapott kérdőívek csak részben igazolták várakozásomat. A válaszadóknak csaknem a fele (43\%) ugyanis tőmondatokban, röviden, egyegy szóval válaszolva, kérdéseket kihagyva töltötte ki a kérdóívet. Olyan eset is volt, amikor megkértek, én foglaljam mondatba, találjam meg a megfeleló kifejezést arra, amit körülírva elmondanak nekem.

Elgondolkodva ezeken az eseteken és a sok tômondatos válaszon, arra a következtetésre jutottam, hogy az elfojtás, az erôs kontroll egyfajta megnyilvánulásával állok szemben. Hasonló következtetéseket találtam Mendi Rózsa kutatásában (Mendi 1999), aki felsőoktatásban tanuló cigány fiatalok személyiségjegyeit vizsgálva azt tapasztalta, hogy az értelmiségivé válás útján e fiataloknak meg kellett tanulniuk nagyon erősen kontrollálni mind negatív, mind pozitív érzelmeiket. 


\section{ÖSSZEGZÉS}

A magyarországi cigányság helyzetének és mentális állapotának felmérésére irányuló kutatásomat 2004 tavaszán végeztem, "hólabda-módszerrel". Így jutottam el a vizsgálatban szereplő 51 értelmiségi, azaz diplomával rendelkező cigány emberhez. A kutatás megkezdése elótt hét hipotézist állítottam fel. A vizsgálatot befejezve, a kapott eredményeket megvizsgálva az alábbi megállapításokat tudom tenni:

- a kutatásomban szereplók - két személy kivételével - elsó generációs értelmiségiek;

- az elsô diploma megszerzéséhez - a nem cigány diplomásoktól eltéróen - gyakran „kanyargós út” vezetett, mintámban nem ritka a középkorú diplomaszerzó;

- a vizsgálatban résztvevók átlagos szomatikus és mentális állapota nem kielégító: 39\% szomatikus betegségektól szenved, 76\%-uk mentális státusa rossz, a korreláció értéke az egészségi állapot és a mentális státus között: 0,46 ;

- a káros szenvedélyek közül a dohányzás előfordulása - az országos átlaghoz hasonlóan - kiemelkedốn magas (49\%);

- a mintában szereplók családi kapcsolatai intenzívek, viszont a rokoni háló gyengülni látszik, 37\% egyáltalán nem tart kapcsolatot a rokonaival;

- úgy túnik, hogy a cigányság körében a civil szerveződés igen aktív, a válaszadók $70 \%$-a tagja valamilyen egyesületnek, alapítványnak;

- a kutatásban résztvevók válaszai alapján a többségi társadalomban az elóítéletes magatartás terén némi javulás látható, hiszen a múltban a mintában szereplôk $61 \%$-a élt át hátrányos megkülönböztetést, ma ugyanezt „csak” $44 \%$ tapasztalja;

- a kutatás eredménye azt mutatja, hogy mind a cigány, mind a nem cigány közösség többsége tisztelettel, megbecsüléssel fogadja a vizsgálatban szerepló diplomás cigány embereket $(68 \%, 60 \%)$;

- a tanult cigány ember sok esetben (32\%) tapasztal elutasítást, kirekesztést saját cigány környezete részéról is.

Kutatásomat lezárva úgy látom, hogy a mai cigány értelmiség, társadalmunk e keskeny, formálódó rétege igen sérülékeny, a többségi társadalom támogatását igényli. A támogatás azonban nem elsósorban segélyeket, a pozitív diszkrimináció gyakran megalázó formáit jelenti, hanem lehetôséget a tanuláshoz, munkához, az egészséges élethez, a megfelelô életkörülményekhez. Elismerését, becsülését annak a munkának, amivel a társadalom pereméról e réteg tagjai az áhított értelmiségi pályára léptek, hogy ne maradjon válasz nélkül a kisebbség kérése: „Sokan várjuk a kapun kívül, hogy bizalmatok rézkrajcárjaival megajándékozzatok" (Bari Károly). 


\section{Irodalom}

Bari K. (1971): Azt hiszitek. In Bari Károly: Holtak arca fölé. Szépirodalmi Kiadó, Budapest. Hermann A. (1895): A Magyarországon 1893. január 31-én végrehajtott czigány összeírás eredményei. Magyar Statisztikai Közlemények. Új Folyam, IX. kötet, Budapest.

Juhász P., Kopp M., Veér A. (1978): Módszer a neurózis szúrốvizsgálatához. Ideggyógyászati Szemle, 31: 292-299.

Kardos I. (1992): Az értelmiség fogalma. In Fónai M.: Értelmiség, értelmiségi funkciók és szerepek. Kandidátusi értekezés, Nyíregyháza, 1995.

Kemény I. (szerk.) (2000): A magyarországi romák. Press Publica, Budapest.

Kopp M., Skrabski Á. (1995): Alkalmazott magatartástudomány. Corvinus Kiadó, Budapest. Liskó I. (2000): Társadalmi esélyek és iskola. Új Pedagóoiai Szemle, 1: 59-63.

Mendi R. (1999): Felsôoktatásban tanuló roma fiatalok pályaszocializációs és személyiségvizsgálata. Bölcsészkari szakdolgozat, ELTE Pszichológiai Intézet.

Sárosi B. (1971): Cigányzene. Gondolat Kiadó, Budapest.

Skrabski Â., Kopp M., Rózsa S., Réthelyi J. (2004): A koherencia mint a lelki és testi egészség alapvetô meghatározója a mai magyar társadalomban. Mentálhigiéné és Pszichoszomatika, 5 (1): 7-25.

Zsuppán A. (2003): Elsó generáció. Magyar Narancs, XV. évf. 20., Oktatási melléklet, 2-4.

\section{SZ. KÁRMÁN, JUDIT \\ SAR SI VON?* \\ THE MENTAL STATUS OF THE INTELLECTUAL OF HUNGARIAN GYPSIES IN THE LIGHT OF A NOT-REPRESENTATIVE SURVEY}

In the last decades the Hungarian gypsies have become more and more self-confident. Since the political change more and more young and less young gipsy-born people are learning in higher education. In contrast with the members of the majority community, their ways were significantly bumpy and essentially longer to get a degree. In my study I searched the possibilities of this stigmatized, minority people for the ascension to the intellectual existence and what price they have to pay for it. I researched who stimulated them to learn, what the reaction of their gipsy and non-gipsy environment to their rise was and whether the attitude of the majority community had changed towards them. Whether they had detached and in what extent they had detached from their roots, whether the traditional, family maintaining contact method still works? I measured their sociological and mental status with questionnaires built up by myself from closed and opened questions. I also used questionnaires which are used in Hungarian and international researches as well.

Keywords: gypsy minority, majority community, intellectual, mental status

\footnotetext{
* How are they? (in gipsy)
} 